\title{
無症候性囊状未破裂動脈瘤治療の問題点
}

\author{
安井 敏裕, 小宮山雅樹, 岩井 謙育, 山中 一浩 \\ 松阪 康弘, 本田 雄二, 吉村 政樹
}

\section{Problems in the Treatment of Asymptomatic Saccular Unruptured Cerebral Aneurysm}

Toshihiro Yasui, M.D., Masaki KomiYama, M.D., Yoshiyasu IwaI, M.D., Kazuhiro Yamanaka, M.D., Yasuhiro Matsusaka, M.D., Yuji Honda, M.D., and Masaki YoshimuRa, M.D.

Department of Neurosurgery, Osaka City General Hospital, Osaka, Japan

Summary: We studied problems in the treatment policies from our treatment experience with 229 cases of asymptomatic saccular unruptured cerebral aneurysm. We used clipping or coiling as needed where the aneurysm was larger than $3 \mathrm{~mm}$, or was located in the dura, and the patient was younger than 70 years, had no serious general disease and had given informed consent.

Clipping was used in 170 cases. The mean age was 57.7 years. In 1 case of a high-positioned basilar tip aneurysm, clipping was considered difficult during operation, so it was changed to coiling. Surgical complications were found in $9.4 \%$ of cases (transient: $5.3 \%$, permanent: $4.1 \%$ ). Venous damage occurred in 5 cases, chronic subdural hematoma in 3 cases, memory loss in 3 cases, tight clipping in 2 cases, aggravation of existing cerebral infarction in 1 case, diminution of vision in 1 case and spasm in 1 case. There were no deaths. In the cases of multiple aneurysm, complications were found frequently when surgery was done in 1 session. Coiling was used in 16 cases. The mean age was 63.3 years. In 1 case of a relatively wide neck basilar tip aneurysm, the stability of the coil was poor, so coiling was changed to clipping. Two cases required blood transfusion or suturing of blood vessels because of hematoma at the puncture site. In 1 case, a cholesterol crystal embolism developed. Combined treatment by clipping and coiling was used in 2 cases. Neither case was problematic. Conservative treatment was used in 41 cases. The mean age was 64.3 years. Sixteen cases were treated conservatively because the patients were older than 70 years. The remaining 25 cases were younger than 70 years but were treated conservatively because the aneurysm was located extradurally (10 cases), serious medical complications were found (5 cases) or treatment was indicated but no informed consent was obtained (10 cases). The aneurysm ruptured and the patient died in 2 cases in which no informed consent was obtained.

Many of the complications in clipping are preventable, so more careful operative procedures are needed. With coiling, complications attendant upon catheterization pose problems. In 2 cases in which the conservative treatment was not given because informed consent was not obtained, the aneurysm ruptured and the patient died. A more positive attitude about obtaining informed consent on the part of neurosurgeons may be needed.

大阪市立総合医療センター 脳神経外科(受稿日 2005.8.15) (脱稿日 2005.9.30)〔連絡先：テ534-0021 大阪市都島区都島本通2丁目 13-22 大阪市立総合医療センター 脳神経外科 安井敏裕] [Address correspondence: Toshihiro YASUI, M.D., Department of Neurosurgery, Osaka City General Hospital, 2-13-22 Miyakojima-hondouri, Miyakojima-ku, Osaka 534-0021, Japan]

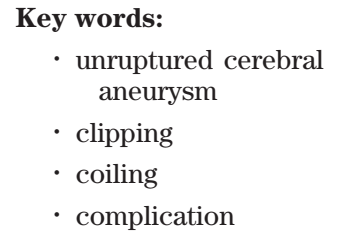

Surg Cereb Stroke (Jpn) 34: 252-256, 2006 


\section{はじめに}

未破裂脳動脈瘤が発見される機会が増えているが, 発見 された場合どのような治療方針を選ぶかについては, 患者 側を納得させられるような十分な evidence が医師側にな く, 訴訟問題などとも相まって症例ごとに困難な選択を迫 られているのが現状である. 今回は，これまでに当院で無 症候性未破裂襄状動脈瘤に対して行ってきたクリッピン グ, コイル塞栓術, 経過観察の各方針に伴う問題点につい て検討したので報告する。

\section{対象と方法}

1993 年 12 月 1 日の開院以来 2005 年 3 月 31 日までに 229 例の無症候性囊状未破裂動脈瘤を経験した。これらの症例 に対する治療適応の原則は，現在の「脳ドックのガイドラ イン 2003」吕とほぼ同じ考え方である。すなわち，1）硬膜 内に存在すること，2) あまり小さくない (3 mm 以上)，3) あまり高齢でない (70歳以下)，4）健康であり全身麻酔下 に手術を行ううえで問題となるような重篤な内科的疾患が ない，5）十分な説明ののちの同意，の5 項目を満たした 場合としてきた．治療を行うことになった場合，クリッピ ングかコイル塞栓術かの選択を行ううえでの確たる条件は ないが，1）瘤の特徵（不整形, neck-to-dome ratio, 動脈 瘤頸部からの分岐血管の有無, 瘤内血栓の有無, 瘤のサイ ズなど)，2）瘤の部位，3）その他 (塞栓術での access routeの有無・適否, 抗血小板剂・抗凝固剂の服用の有無, 脳萎縮の程度など)，4）bias (患者側の知識量・好み, 術 者の力量など)などを考慮し適宜選択してきた.

\section{結 果}

\section{1. 治療法の選択}

229 例の治療の内訳は，クリッピング 170 例 $(74 \%)$ ，コ イル塞栓術 16 例 (7\%)，クリッピングおよびコイル塞栓術 の併用 2 例 (1\%), 経過観察 41 例 (18\%) であった.

i) クリッピング $(\mathrm{n}=170)$

年齢は 20-74 歳 (平均 57.7 歳)。脳底動脈先端部動脈瘤の 1例では pterional approachでクリッピングを試みたが, 高位であったため対側穿通枝の確認が十分にできず，クリ ッピングを断念しコイル塞栓術に変更した。手術合併症は 一過性を含めると 16 例 (9.4\%) であったが, 永続的な症状 を残したものは 7 例 (4.1\%)のみであった (Table 1). 多発 性未破裂脳動脈瘤症例で手術を行ったものが 29 例あった. そのうち，1つのアプローチルートでクリッピング可能で あった 11 例では合併症は生じなかった．2つのアプロー チルートを要する場合には，二期に分けて行った症例 12 例では合併症がなく，一期的に行った 6 例中 2 例（33\%）
Table 1 Complications in surgery for unruptured intracranial saccular aneurysms

\begin{tabular}{ll}
\hline Venous infarction & $5(1)$ \\
Chronic subdural hematoma & $3(0)$ \\
Memory disturbance & $3(3)$ \\
Tight clipping & $2(2)$ \\
Aggravation of infarction & $1(1)$ \\
Visual decline & $1(0)$ \\
Spasm & $1(0)$ \\
\hline & $16(7)$
\end{tabular}

The number in the parentheses indicates the patients with permanent neurological deficits.

では合併症を生じていた。この 2 例は，いずれも静脈損傷 によるものであった(Fig. 1).

ii) コイル塞栓術 $(\mathrm{n}=16)$

年齢は 40-80歳 (平均 63.6歳).やや wide neck の脳底動 脈先端部動脈瘤の 1 例ではいったん瘤内へコイルの誘導ま で行ったが，瘤内でのコイルの安定性が悪かったために detachmentを断念し, pterional approachによるクリッ ピングに変更した (Fig. 2)，神経症状を伴う塞栓性合併症 を生じた例はなかったが，術後にMRIが行われていた 10 例中 3 例 (30\%) において無症候性の小梗塞が出現していた (Fig. 3).また，1-3年の経過では coil compaction を生じ た例はなかった．穿刺部に大きな血腫を生じ輸血を要した 例が 2 例あり，このうち 1 例では穿刺部股動脈に仮性動脈 瘤を形成したため，瘤切除・血管形成術を要した。また， 後大脳動脈瘤を有した大動脈炎症候群の 1 例において, 経 皮的血管形成術と同時に瘤のコイル塞栓術を施行したとこ 万, 施行後 3 日目にblue toe, 急性腎不全, 肝機能障害, eosinophilia，CRP值上昇などを呈し，コレステロール塞 栓症と診断された。

iii）クリッピングおよびコイル塞栓術の併用治療 $(\mathrm{n}=2)$

1 例 (60歳, 女性) は左側内頸-後交通動脈瘤と血栓化大 型前大脳動脈瘤の 2 個を有する症例で前者をコイル塞栓 し，後者をクリッピングした。他の 1 例 (72歳，女性) は 前大脳動脈瘤と中大脳動脈瘤を有する症例で前者をコイル 塞栓し後者をクリッピングした。

iv）経過観察 $(\mathrm{n}=41)$

年齢は 30-84 歳 (平均 64.3歳)。経過観察の方針となった 理由で最も多かったものは 70 歳以上という年齢で，16例 であった。このうち $8 \mathrm{~mm}$ 径の前交通動脈瘤症例 (70歳, 女性)が 1 年後に破裂した。本例ではコイル塞栓を行い, 軽症であったため GR となった。残り 25 例は 70 歳未満で はあったが, 硬膜外内頸動脈瘤の 10 例と痴呆・悪性腫瘍 などの疾患が問題となった 5 例では医師側で治療適応なし と判断した。これら 15 例では経過中に破裂をきたした症 

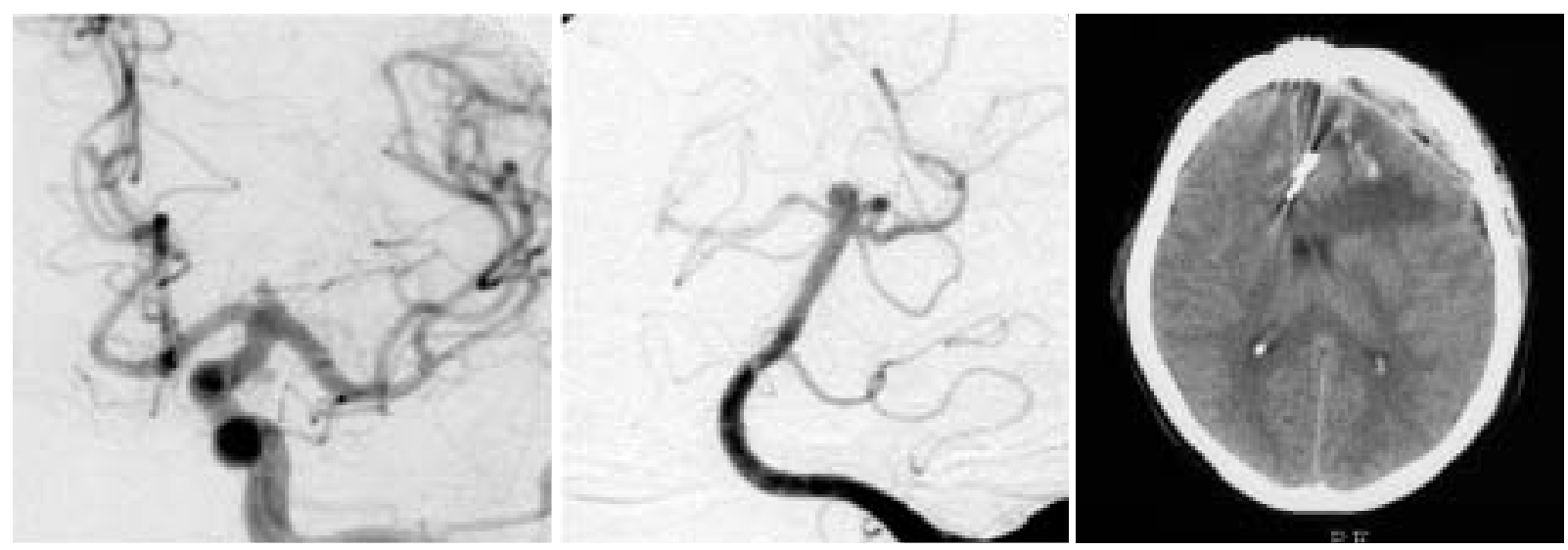

Fig. 1 Carotid angiogram (leff), vertebral angiogram (center) and postoperative CT scan (right). left: An internal carotid-anterior choroidal aneurysm, an internal carotid artery bifurcation aneurysm and a distal anterior cerebral artery aneurysm are shown. center: A basilar tip aneurysm is shown.

A distal anterior cerebral artery aneurysm was clipped through the left interhemispheric approach and the other three aneurysms were obliterated via the left pterional approach in one session.

right: Left frontal lobe venous infarction developed postoperatively owing to the sacrifice of the frontal bridging vein.
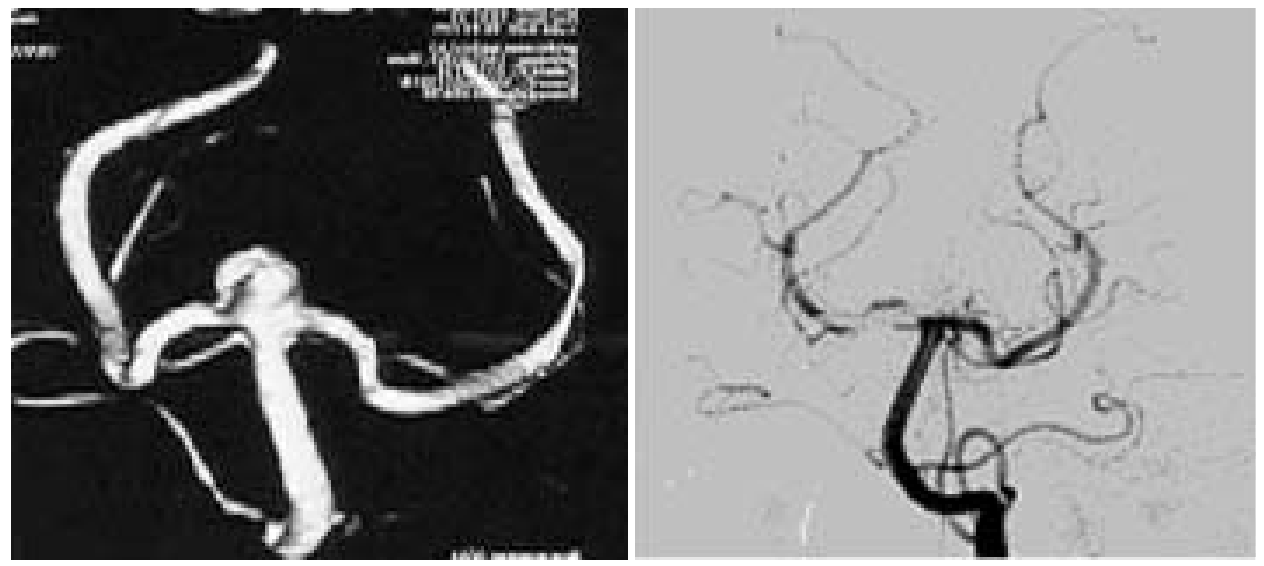

Fig. 2 Vertebral, anteroposterior pre- (leff) and postoperative (right) angiograms showing a relatively wide neck basilar tip aneurysm.

例はなかった. 残り 10 例は医師側としては治療の適応が あると考えたが, 患者側と治療に関して同意に到らず経過 観察となった。この 10 例中, 大型内頸-後交通動脈瘤症例 (63歳, 女性) が 6 年後に, 大型脳底動脈先端部動脈瘤症 例 (52 歳, 男性)が 1 年後に破裂し, いずれも grade 5 と重 症で根治的治療をできずに死亡した(Fig. 4).

\section{考察}

MRIの普及や脳ドックへの関心の高まりで，未破裂脳 動脈瘤の発見される機会が増えている。しかし, いったん みつかった未破裂脳動脈瘤は，未治療で放置した場合には 患者に種々の程度のストレスを与えることになり, quali- ty of life が低下することがある ${ }^{3)}$. 2003 年に日本脳ドック 学会から治療ガイドライン ${ }^{6)}$ が出されたが，患者側の多く の疑問に答えられるだけの evidence はなく，医師側ある いは患者側が有する多くの biasに影響されながら治療の 同意に到った場合に，クリッピングないしコイル塞栓術が 行われるという，いわばNBM (narrative based medicine) 9)によって決まっているのが現状である.

破裂率に関しては，通常，治療の対象になるような 5-10 mmのものについては，極端に低い報告もあるがお おむね $1 \%$ /年と思われる。しかし，日本の未破裂動脈瘤の 破裂率は日本以外の報告に比べて高く $2.7 \%$ になるという 報告もあり，国別の破裂率も考慮する必要性があるともい 

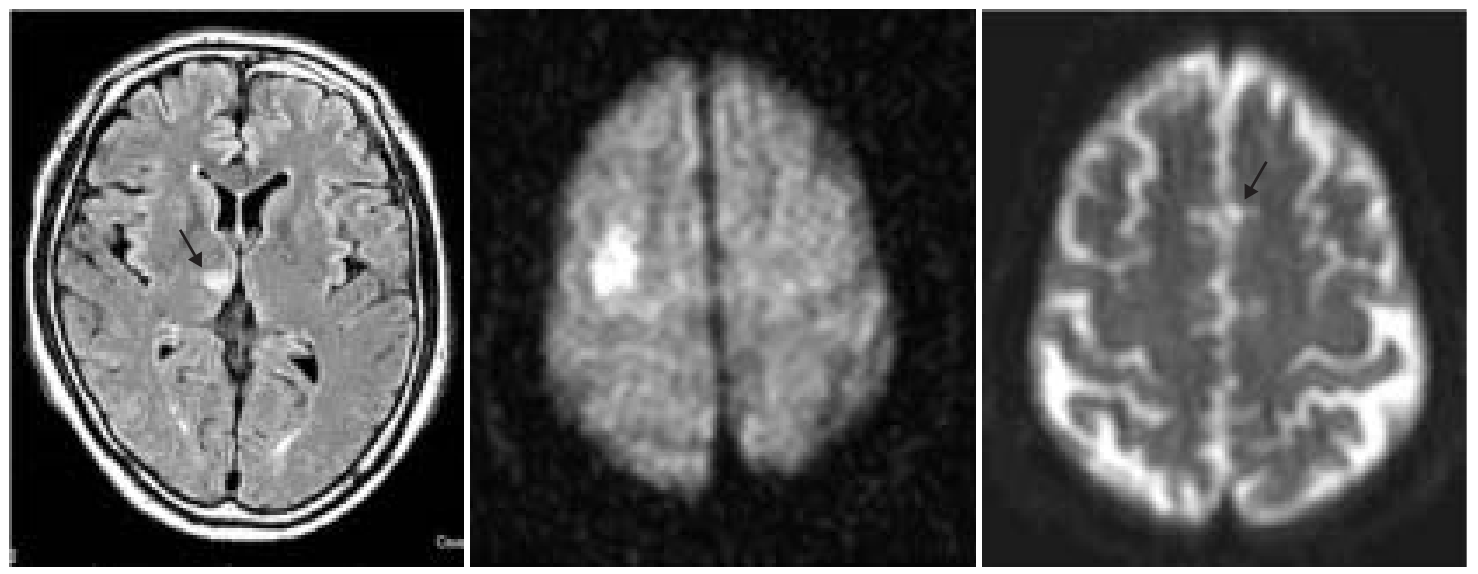

Fig. 3 Three patients, 30\% of the patients undergoing postembolization MRI demonstrated a newly developed cerebral infarction.

left: A small right thalamic infarction (arrow) was demonstrated on a FLAIR MRI in the patient with a basilar tip aneurysm.

center: A small infarction in the right frontal lobe was disclosed on a diffusion-weighted MRI in the patient with a posterior cerebral artery aneurysm.

right: A small infarction in the paramedian frontal lobe (arrow) was found on a T2-weighted MRI in the patient with a distal anterior cerebral artery aneurysm.
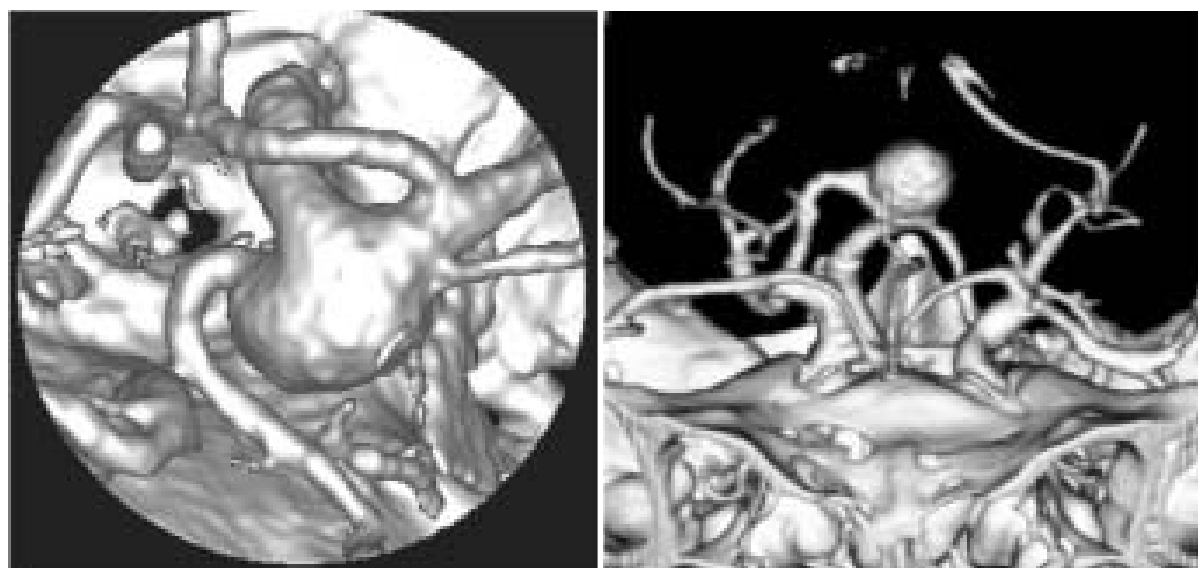

Fig. 4 3D-CT angiograms.

left: A large internal carotid-posterior communicating aneurysm with a wide neck. right: A large, high-positioned basilar tip aneurysm.

Both aneurysms ruptured fatally.

われている4).

2003 年の日本脳ドックのガイドライン ${ }^{6)}$ では未破裂脳動 脈瘤が発見された場合の医学情報については正確かつ詳細 なインフォームドコンセントの必要性が強調されている. このことは医療過誤訴訟のデータをみてもうなずける. 2003 年の主な医療側の過失認定判決をみると外科系が多 く, 特に脳神経外科 6 件のうち未破裂脳動脈瘤のクリッピ ング術を巡るものが 4 件と目立ち， 2 件は手技上の過失， 1 件は適応を欠くとされ，もう 1 件は説明義務違反に問わ れている1).
本論文では, 未破裂脳動脈瘤患者に対してクリッピング, コイル塞栓術, 両者の併用治療および経過観察の 4 つの方 針を選択した場合の問題点を報告した。クリッピングに関 しては，これまでに手術の risk factorとして，(a) 脳梗 塞, (b) 高齢者 (65 歳以上, 特に 70 歳以上), (c) 大きな 動脈瘤 (10 $\mathrm{mm}$ 以上, 特に $15 \mathrm{~mm}$ 以上), (d) 脳底動脈瘤, (e) 全身合併症などが知られている ${ }^{7)}$. 本論文で報告した 著者らの手術合併症も, 非常にまれな spasmの例を除 き10)，すべてこれまでに報告されたものばかりである. これらの合併症はさらなる慎重な手術操作と経験を積めば 
減らすことは可能かもしれないが，同じ治療結果が得られ るのであれば，侵襲性の低いコイル塞栓術を選択するのが 当然と考える。

一方，コイル塞栓術の場合には低侵襲ではあるが，長期 成績があまりない点が問題となる。さらに，2例において 穿刺部に大きな血腫を作り，ともに高齢者であったため， 貧血による全身倦急感を呈して発見されたことはカテーテ ル法に伴う合併症として注意を要する．2例とも輸血を行 う必要があり，1例では仮性動脈瘤を形成していたため手 術も要した。また，1例で経験したコレステロール塞栓症 は cholesterol crystal embolismともいわれ, 大血管の粥 状動脈硬化のプラークから微小なコレステロール結晶が遊 離し末梢塞栓をきたして多発性臟器虚血を生じる疾患で, カテーテル検査やカテーテル治療後にまれに起こりうる重 大な合併症であり，しばしば予後不良である．発症が緩徐 な例があり, eosinophilia や低補体血症がみられる例があ ることから微小塞栓に加え, アレルギー反応を介した血管 炎や内皮障害が関与している可能性があるとされている. いずれにせよ，カテーテル検査や治療に際して起こりうる 疾患としてインフォームドコンセントに際して勘案する必 要があると思われる ${ }^{5)}$.

保存的治療を行った症例中 10 例は医師側としては治療 の対象と考えたが, 治療に伴うリスクの点で患者側と同意 に到らなかった。このうち，2例が grade 5 の破裂で死亡 した、いずれの症例も十分なるインフォームドコンセント の結果として選択した保存的治療であったため，家族との 信頼関係もあり，medicolegal な問題とはならなかった。 これまでに破裂の危険因子として喫煙と高血圧が知られて おり ${ }^{2)}$, 保存的治療としては禁煙と血圧管理を行うことに なる。しかし，最近の研究では，降圧剂を投与していても 1 日の血圧管理が正しく行われている例はわずか $21 \% に す$ ぎず，全体の $79 \%$ は血圧管理が不十分であることが確認 されている ${ }^{8)}$.すなわち，降圧剤投与イコール血圧管理と 考えるのは早計と思われる。したがって未破裂脳動脈瘤を クリッピングないしコイル塞栓術で適切に処理するという 選択肢は “avoidable death”という観点から非常に有用
な手段であり，いったん保存的治療で同意に到った場合で あっても，治療法の進歩・改善に連動して，治療方針の変 更を行うことも重要であると考える.

\section{結 語}

1. クリッピング, コイル塞栓術のいずれの治療法にも, それぞれの手技に特有の合併症が生じている。

2. 保存例に扔いては，医師側が治療対象と考えながらイ ンフォームドコンセントに到らなかったため治療を行 っていない例では，時期を変えての再度の説明や，よ り厳重な血圧管理や禁煙が必要と思われた。

最後に，本論文の要旨は第 34 回日本脳卒中の外科学会 （2005，仙台)にて発表した.

\section{文献}

1）浅井登美彦：検証・2003 年の医療過誤訴訟 Nikkei Medical, 2004 年 4 月号, 2004, pp79-86

2) Juvela S, Porras M, Poussa K: Natural history of unruptured intracranial aneurysms: probability of and risk factors for aneurysm rupture. J Neurosurg 93: 379-387, 2000

3) King JT Jr, Glick HA, Mason TJ, et al: Elective surgery for asymptomatic, unruptured, intracranial aneurysms: a cost-effectiveness analysis. $J$ Neurosurg 83: 403-412, 1995

4) Morita A, Fujiwara S, Hashi K, et al: Risk of rupture associated with intact cerebral aneurysms in the Japanese population: a systematic review of the literature from Japan. J Neurosurg 102, 601-606, 2005

5） 中原一郎, 渡邊芳彦, 東 登志夫, ほか：頸動脈ステント 留置術に続発したコレステロール塞栓症の1例。Jpn J Neurosurg 13: 583-587, 2004

6）脳ドックのガイドライン 2003 ：日本脳ドック学会 脳ドッ クの新ガイドライン作成委員会編集，2003 年 9 月発行

7）斎藤 勇：無症候性脳動脈瘤：その対応と問題点. 脳外 24: 875-884, 1996

8）島田和幸：クローズアップされてきた早朝高血圧とこれか らの血圧管理. Therapeutic Research 25: 1579-1584, 2004

9）トリシャ・グリーンハル，ブライアン・ハーウイッッ：ナ ラティブ・ベイスト・メディスン．金剛出版，東京，2001

10）安井敏裕，小宮山雅樹，岩井謙育，ほか：未破裂脳動脈瘤 術後の虚血性合併症．脳卒中の外科 $31: 104-110,2003$ 